\title{
Radiographic analysis for the evaluation of polyembryony in Swingle citrumelo seeds ${ }^{1}$
}

\author{
Natália Arruda $^{2 *}$, Silvio Moure Cicero ${ }^{2}$, Francisco Guilhien Gomes Junior ${ }^{2}$
}

\begin{abstract}
The polyembryony rate is a very important factor to consider when choosing a commercial rootstock. Currently, automated systems are used to improve seed quality analyses. X-ray testing is a fast, simple, non-destructive, high-precision test that allows to examine in detail the internal morphology of the seeds to identify damaged areas, their location and types of damage. In this context, the present research aimed to verify the possibility of using X-ray test to evaluate the polyembryony in Swingle citrumelo seeds. Seeds from seven lots were submitted to X-ray tests, direct method (embryo counts) and indirect method (germination). According to the results obtained, it was observed that there was a high coincidence between the number of embryos per seed analyzed using X-ray test and the direct method. Radiographic image analysis is efficient to evaluate the polyembryony in seeds of Swingle citrumelo.
\end{abstract}

Index terms: image analysis, rootstock, internal morphology, embryos.

\section{Análise radiográfica para avaliação da poliembrionia em sementes de citrumelo 'Swingle'}

\begin{abstract}
RESUMO - A taxa de poliembrionia é um caráter de grande importância na escolha de um porta-enxerto comercial. Atualmente, sistemas automatizados são utilizados para aprimorar as análises de qualidade de sementes, dentre eles o teste de raios X, que é rápido, simples, não destrutivo e de alta precisão. Ele possibilita examinar com detalhes a morfologia interna da semente, identificar áreas danificadas, sua localização e os tipos de danos. Neste contexto, a presente pesquisa teve como objetivo verificar a possibilidade de utilização do teste de raios X para avaliar a poliembrionia em sementes de citrumelo 'Swingle'. Sementes provenientes de sete lotes foram submetidas ao teste de raios X, ao método direto (contagem de embriões) e ao método indireto (germinação). De acordo com os resultados obtidos, observou-se que o número de embriões por semente analisados por meio do teste de raios X obteve alta coincidência com o método direto. A análise de imagens radiográficas é eficiente para avaliar a poliembrionia das sementes de citrumelo 'Swingle'.
\end{abstract}

Termos para indexação: análise de imagens, porta-enxerto, morfologia interna, embriões.

\section{Introduction}

Brazil is the world's largest producer of sweet orange and the largest orange juice exporter, with the state of São Paulo accounting for $74.5 \%$ of the national production (IBGE, 2017). The most utilized cultivar in Brazilian citriculture is the Pera orange, which corresponds to $35.7 \%$ of the citrus trees. The predominance of this cultivar and the low diversity of rootstocks have increased the incidence of several diseases, such as citrus tristeza, citrus variegated chlorosis, citrus sudden death and huanglongbing (HLB), all of which cause great economical losses (Fadel et al., 2014; Yamamoto et al., 2014; Leonel et al., 2015). Currently, Swingle citrumelo is the most commonly used rootstock for diversification of orange groves in state of São Paulo (Pompeu Junior and Blumer, 2011).

Rootstocks are obtained from polyembryonic seeds. In this case, besides the zygotic embryo, nucellar embryos are formed from the parent tissue. For rootstock cultivation, the nucellar seedlings are very important, because they are disease-free and identical to their parent plant. The

${ }^{1}$ Submitted on 01/31/2017. Accepted for publication 02/07/2018.

${ }^{2}$ Departamento de Produção Vegetal, USP/ESALQ, Caixa Postal 9, 13418-900 - Piracicaba, SP, Brasil.

*Corresponding author <nathy.a@hotmail.com> 
polyembryony rate is extremely important when choosing a commercial rootstock, because the higher the rate, the greater are the chances of forming rootstocks from nucellar origin, therefore similar to the parent plant, when propagation by seeds is performed (Moreira et al., 2010).

Polyembryony can be assessed by counting the number of seedlings after germination, or by obtaining the number of embryos in the seeds. Despite being more laborious, the direct count gives more consistent and reproducible results (Pompeu Junior, 2005).

Among the resources available for seed analysis, the use of the X-ray test, a technique recommended by the International Seed Testing Association - ISTA (2004), is very important for many seed species, since it is a non-destructive, rapid test, with the basic purpose of studying the internal morphology of seeds.

The X-ray test has been used in seed researches since the 1950s, when Simak and Gustafsson (1953) demonstrated its potential for evaluating the quality of seeds of Pinus sylvestris L. Thus, this technique was used in genetic improvement works, allowing the detection of abnormalities in embryos and the determination of their development stage, and also in the isolation of mutant embryos of Arabidopsis thaliana (Bino et al., 1993). The technique also allowed to correlate the internal morphology of seeds with the germination or with the morphology of seedlings from several agriculture or forest species (Machado and Cicero, 2003; Oliveira et al., 2003; Pupim et al., 2008; Pinto et al., 2009; Carvalho et al., 2010; Gagliardi and Marcos-Filho, 2011; Socolowski et al., 2011; Kobori et al., 2012; Silva, et al., 2013; Rocha et al., 2014; Silva et al., 2014; Silva et al., 2014; Arruda et al., 2016).

In the literature, there is no scientific work using image analysis for the evaluation of the internal morphology of citrus seeds. Hence, the study of this technique is very important for determining polyembryony in seeds of citrus and other species, seeing it provides valuable information and knowledge on the quality control of these seeds. Therefore, the objective of this work was to verify the possibility of using X-ray testing to evaluate polyembryony of Swingle citrumelo seeds.

\section{Material and Methods}

The study was carried out at the laboratories of Image Analysis and Seed Analysis, both part of the Plant Production Department of the Escola Superior de Agricultura Luiz de Queiroz, Universidade de São Paulo, city of Piracicaba, state of São Paulo (SP), Brazil. Seven seed lots of the hybrid rootstock Swingle citrumelo were used (Citrus paradisi Macfad. cv. Duncan x Poncirus trifoliata (L.) Raf.) from the 2014 crop year. The seeds were produced in the city of Gavião Peixoto (SP). They were mechanically extracted from ripe fruits, treated with the fungicide Captan 500 PM (100 g i.a./100 $\mathrm{kg}$ of seeds), and then sent to be evaluated according to the following tests.

Moisture content: it was assessed before the X-ray and the germination tests were performed, by the oven method, at $105^{\circ} \mathrm{C}$ for 24 hours (Brasil, 2009) in two $5 \mathrm{~g}$ subsamples. The results were expressed as mean percentage (wet basis, w.b.) per lot.

$X$-ray tests: they were conducted in sixteen replications of 12 seeds and one replication of 8 seeds per lot, totaling 200 seeds x-rayed for the direct method (embryo counts) and 200 seeds $\mathrm{x}$-rayed for the indirect method (germination). The seeds were placed on a transparent acetate sheet with $210 \times 297 \mathrm{~mm}$ dimensions, with a transparent double-sided adhesive tape to hold them in the correct position (all seeds were positioned with the embryonic axis facing downwards). The seeds were then numbered according to their position on the acetate sheet, so that they could be identified in the following evaluations. Then, the acetate sheet and the seeds were put inside a digital X-ray machine (Faxitron ${ }^{\circledR}$ model MX-20 DC-12) connected to a computer preset for radiation intensity. The seeds were positioned $28.6 \mathrm{~cm}$ far from the radiation source. The images generated were saved on a computer hard drive for further analysis.

The $\mathrm{x}$-rayed seeds were transferred from the acetate sheet to a plastic tray with individual numbered cells, in the same order as they had been placed on the acetate. After that, they were submitted to the direct and indirect methods for evaluation of polyembryony. After analyzing each X-ray image, the frequency distribution of embryos, the mean number of embryos per seed, and the polyembryony rate were determined.

The frequency distribution of embryos was determined by the equation $\mathrm{DF}=$ (number of seeds with one or more embryos) $x$ (total number of seeds) $)^{-1} x(100)$. The mean number of embryos per seed was obtained by the equation $\mathrm{E} / \mathrm{S}=$ (total number of embryos) $\mathrm{x}$ (total number of seeds) $)^{-1}$. The polyembryony rate was obtained by the expression $\mathrm{Pol}=$ (number of seeds with more than one embryo) $\mathrm{x}$ (total number of seeds $)^{-1} \mathrm{x}(100)$.

Direct method (embryo counts): after the X-ray tests, the seeds were transferred to a plastic tray with individual cells. The cells were filled with water, and the tray was placed in a germinator at $30{ }^{\circ} \mathrm{C}$ for 24 hours to avoid damaging the seeds or losing cotyledons. After this procedure, the tegument was removed from each seed, and the embryos were counted, in order to determine the percentage of distribution of the embryos, the mean number of embryos per seed and the percentage of polyembryony for each lot.

Indirect method (germination): after the X-ray, the germination test was set on paper towels moistened with water in the mass ratio of 1:2.5 (paper:water). The previously numbered (identified) seeds were distributed on two paper 
towel sheets (on the upper-third of the substrate, to allow an individualized seedling development) and covered with another sheet. The rolls were kept in germinator at $25^{\circ} \mathrm{C}$, and the evaluation was performed on the fifty-sixth day after the sowing, according to the criteria presented in Regras para Análise de Sementes (Brasil, 2009).

This allows to determine the percentage of distribution of embryos, the mean number of embryos per seed, and the percentage of polyembryony in each lot. Subsequently, the seeds with one or more seedlings were photographed with a digital camera, and the images were saved in the hard drive of a computer for further analysis.

In order to evaluate the efficiency of the X-ray test, the number of embryos in each seed (determined by the direct and indirect methods) was compared with the results obtained by the X-ray for each seed. This way, it was possible to determine the percentage of seeds in which the number of embryos per seed coincided (or not) with the respective methods.

The results from the image analysis were not statistically analyzed. The interpretation of the X-ray results was confronted with the number of embryos observed by the direct method, and with the photos of normal and abnormal seedlings from the indirect method (germination test).

\section{Results and Discussion}

The moisture content of the seeds ranged from $28.7 \%$ to $29.9 \%$. According to Simak (1991), the moisture content influences the optical density, that is, the lower the moisture, the greater the optical density, which allows a better differentiation of the internal parts of the seed on the radiographs. Thus, the high moisture content of the seeds influenced the sharpness of the images.

In X-ray analysis carried out in wild seeds of Persea pyrifolia (Carvalho et al., 2009) and Euterpe edulis Martius (Cursi and Cicero, 2014), there were also difficulties to visualize the structure of seed with water content above $30 \%$, but it was possible to notice morphological alterations. It is important to highlight that each species possess typical characteristics of density and chemical composition, factors that significantly interfere in the visualization of the x-rayed part of the seeds.

The X-ray and the direct method analyses of some seeds could not be conducted, due to the high degree of deterioration. So, these seeds were classified as dead and excluded from the evaluations of frequency distribution of embryos, number of embryos per seed and polyembryony. Therefore, the number of seeds showed variation in all tests performed. In the X-ray test, the number of seeds ranged from 177 to 198 (lots 4 and 1 , respectively), and in the direct method, it ranged from 156 to 194 (lots 4 and 1, respectively) (Table 1).

Table 1 shows the number of seeds, number of embryos, frequency distribution of embryos, mean number of embryos per seed, and polyembryony rate of each lot. These analyses were performed in order to verify the efficiency of the X-ray tests. In general, the outcomes from all X-ray analyses were similar to those obtained by the direct method, although the latter provided higher values.

The frequency distribution of embryos showed similar percentage of seeds with the same number of embryos both in the X-ray test and in the direct method, for the majority of the lots. In the X-ray test, it was possible to identify and quantify up to 5 embryos per seed (lots 3, 4 and 7) (Figure 1a). By the direct method, besides the lots 3, 4 and 7, lot 2 also presented seeds with 5 embryos (Figure 1b).

The mean number of embryos per seed in each lot determined by the X-ray test ranged from 1.7 (lots 6 and 7) to 2.0 (lots 3 and 4). Similar result was observed by the direct method, with mean number of embryos per seed between 1.8 (lot 7) and 2.1 (lots 3,4 and 5). As for the polyembryony rate, the results got from the X-ray test for each lot stayed between $53 \%$ and $71 \%$ (lots 7 and 5, respectively), whereas those obtained by the direct method ranged from $58 \%$ to $74 \%$ (lots 7 and 4, respectively). Consequently, no differences in the polyembryony rate results of the lots were observed between these two methods (Table 1).

Embryos of different sizes and shapes were observed in the X-ray test and in the direct method. According to Frost and Soost (1968), citrus embryos have fleshy cotyledons, which make up the bulk part of the mature embryo. In monoembryonic citrus seed, the embryo usually showed two cotyledons practically identical in size and shape (Figure 2), but seeds with two embryos displayed cotyledons with different sizes (Figure 3).

In addition, seeds with more than three embryos presented irregular-shaped cotyledons, in comparison with monoembryonic seeds (Figure 4). Mendes da Glória et al. (2001) also observed those morphological variations in embryos of Valencia Orange seeds. According to these authors, the distinct variations in the cotyledons are a characteristic of nucellar embryos, and they can be explained by the competition for space inside the seed.

In the direct method, it was possible to verify that some embryos were rudimentary, small and thin, especially those in seeds with more than three embryos, which were difficult to identify through the X-ray test. In some cases, these embryos can be mistaken for deteriorated tissues, because their coloration in the X-ray image appears in darker shades of gray, in comparison to seed regions with denser, thicker 
Table 1. Results of number of seeds (S), number of embryos (E), frequency distribution of embryos, number of embryos per seed (E/S) and polyembryony (Pol) of seven lots of Swingle citrumelo seeds analyzed by X-ray and by the direct method (embryo counts).

\begin{tabular}{|c|c|c|c|c|c|c|c|c|c|}
\hline \multicolumn{10}{|c|}{$\mathrm{X}$-ray test } \\
\hline \multirow{2}{*}{ Lot } & \multicolumn{2}{|c|}{ Number } & \multicolumn{5}{|c|}{ Frequency distribution of embryos (\%) } & \multirow{2}{*}{$\mathrm{E} / \mathrm{S}$} & \multirow{2}{*}{$\begin{array}{c}\text { Pol } \\
\%\end{array}$} \\
\hline & $\mathrm{S}$ & E & 1 & 2 & 3 & 4 & 5 & & \\
\hline 1 & 198 & 356 & 38 & 45 & 16 & 1 & 0 & 1.8 & 62 \\
\hline 2 & 190 & 333 & 43 & 40 & 15 & 2 & 0 & 1.8 & 57 \\
\hline 3 & 185 & 361 & 38 & 36 & 20 & 5 & 1 & 2.0 & 62 \\
\hline 4 & 177 & 359 & 30 & 42 & 24 & 3 & 1 & 2.0 & 70 \\
\hline 5 & 187 & 362 & 29 & 51 & 17 & 3 & 0 & 1.9 & 71 \\
\hline 6 & 191 & 329 & 44 & 41 & 14 & 1 & 0 & 1.7 & 56 \\
\hline 7 & 190 & 326 & 47 & 37 & 12 & 3 & 1 & 1.7 & 53 \\
\hline \multicolumn{10}{|c|}{ Direct method } \\
\hline \multirow{2}{*}{ Lote } & \multicolumn{2}{|c|}{ Número } & \multicolumn{5}{|c|}{ Frequency distribution of embryos (\%) } & \multirow{2}{*}{$\mathrm{E} / \mathrm{S}$} & Pol. \\
\hline & $\mathrm{S}$ & $\mathrm{E}$ & 1 & 2 & 3 & 4 & 5 & & $\%$ \\
\hline 1 & 194 & 378 & 33 & 44 & 19 & 4 & 0 & 1.9 & 67 \\
\hline 2 & 177 & 358 & 31 & 42 & 21 & 5 & 1 & 2.0 & 69 \\
\hline 3 & 160 & 340 & 29 & 40 & 21 & 8 & 2 & 2.1 & 71 \\
\hline 4 & 156 & 330 & 26 & 42 & 26 & 5 & 1 & 2.1 & 74 \\
\hline 5 & 179 & 378 & 27 & 40 & 27 & 6 & 0 & 2.1 & 73 \\
\hline 6 & 186 & 347 & 37 & 41 & 19 & 3 & 0 & 1.9 & 63 \\
\hline 7 & 189 & 341 & 42 & 40 & 14 & 4 & 1 & 1.8 & 58 \\
\hline
\end{tabular}

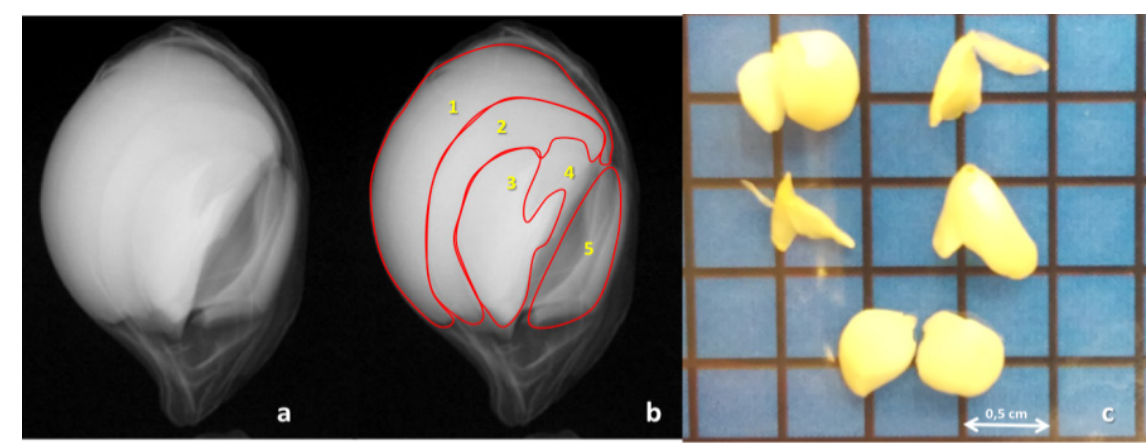

Figure 1. X-ray images of seeds of Swingle citrumelo (a) with the delimitations of each embryo (b), and five embryos, obtained by direct method (c).

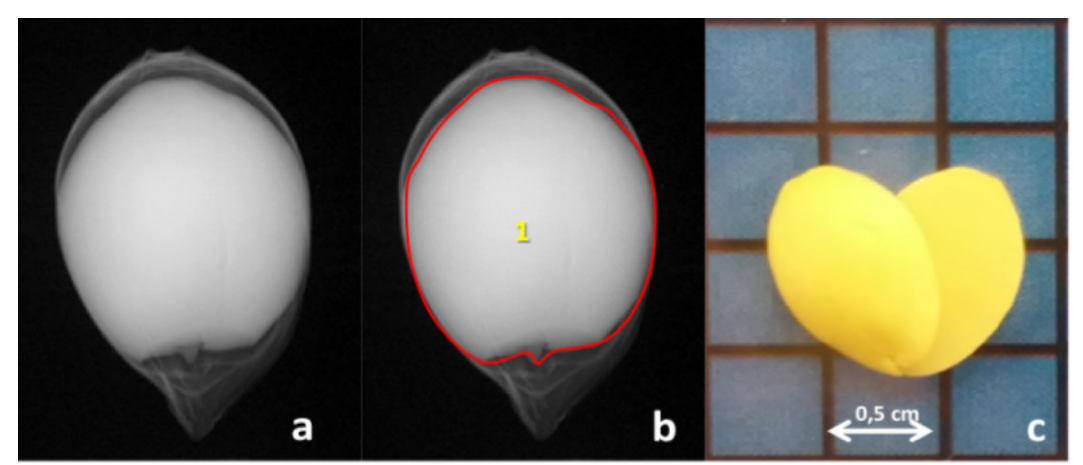

Figure 2. X-ray images of a monoembryonic seed of Swingle citrumelo (a) with the delimitations of the embryo (b), and embryo obtained by the direct method (c). 


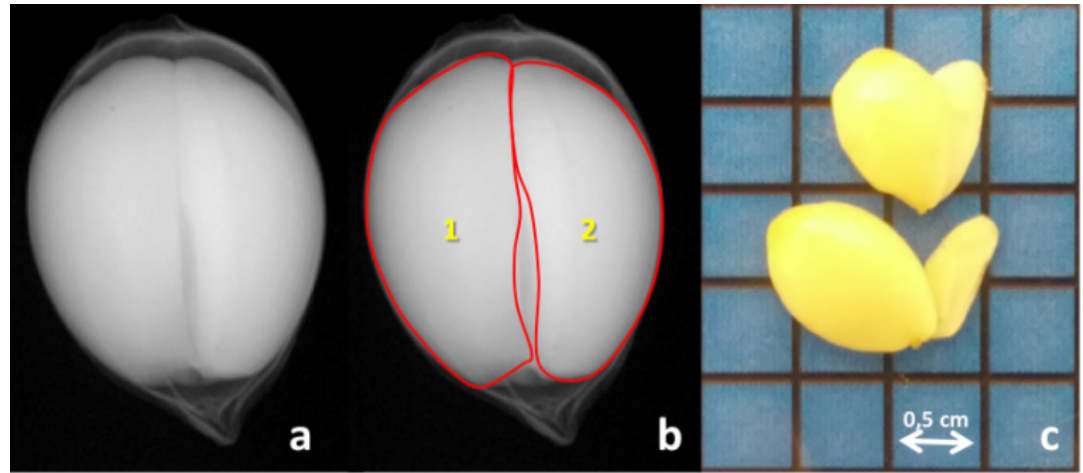

Figure 3. X-ray images of a polyembryonic seed of Swingle citrumelo (a) with the delimitations of each embryo (b), and embryos obtained by the direct method (c).

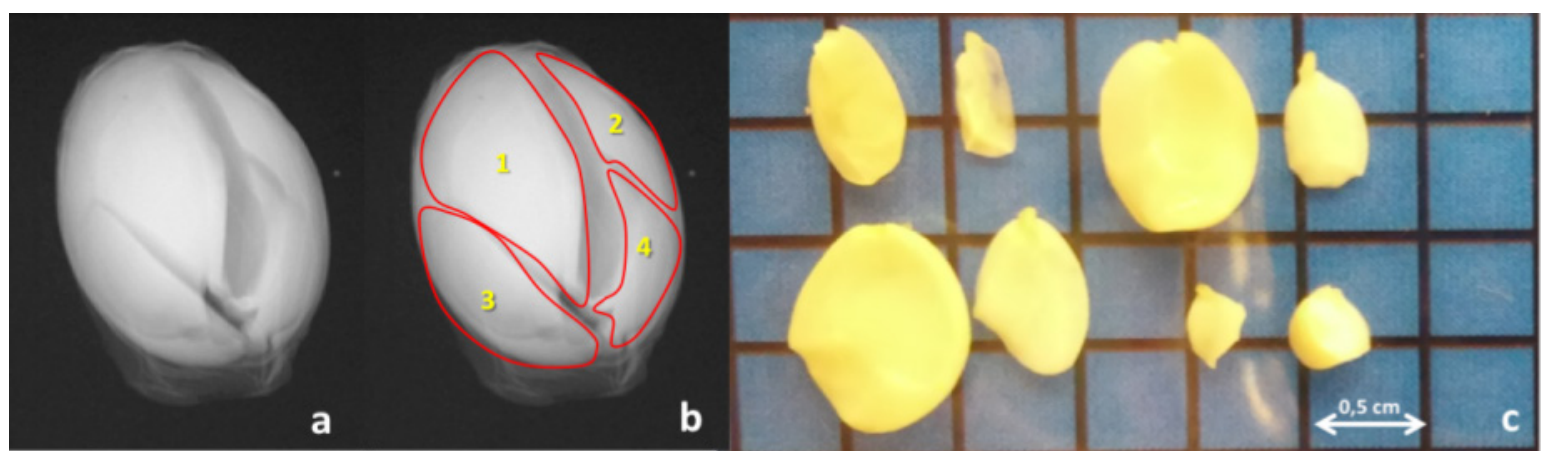

Figure 4. X-ray images of a polyembryonic seed of Swingle citrumelo (a) with the delimitations of each embryo (b), and embryos with different sizes and shapes, obtained by the direct method (c).

tissues. Table 2 shows the results of the frequency distribution of embryos, mean number of embryos per seed, mean number of seedlings and polyembryony, analyzed by the X-ray test and the indirect method. In general, the results obtained from all X-ray image analyses were greater than those obtained by the indirect method.

In the X-ray test, the number of seeds analyzed varied from 187 to 197 (lots 6 and 1, respectively); and in the indirect method, it varied from 102 to 144 (lots 5 and 2, respectively). The number of seeds observed through the indirect method was considerably lower than in the other tests, possibly because the indirect method is subjected to several factors, such as seed physiological potential, temperature, and others that may influence germination, besides the fact that only seeds that originated normal seedlings were accounted.

In addition, the X-ray tests allowed to identify and quantify up to 4 embryos in each seed (lots 1,2 and 5), whereas in the indirect method this occurred only in lot 1. It is important to notice that, by the indirect method, a high percentage of seeds with only one seedling was observed (values between $76 \%$ and $93 \%$ ), differently from the X-ray results (from $49 \%$ to $62 \%$ ). The high percentage of seeds with only one seedling, by the indirect method, interfered directly in the mean number of seedlings per seed, which ranged from 1.1 to 1.2. These results were lower than those of the X-ray test, which varied from 1.6 to 1.8. Furthermore, it interfered in the percentage of polyembryony ( $7 \%$ to $24 \%$ ), which was lower than that observed by the X-ray method (49\% to $62 \%$ ). Carvalho and Silva (2013) also verified that the mean percentage of polyembryony of Swingle citrumelo seeds was $18.84 \%$.

Studies on the cultivation and conversion of nucellar embryos into plants of different cultures (Wetzstein and Baker, 1993; Rodriguez and Wetzstein, 1994; Padmanabhan et al., 1998) related the low conversion rates with abnormalities in the apical meristem of the embryo radicle. In polyembryonic varieties of the genus Citrus, the presence of malformed nucellar embryos could explain the medium index of normal seedling formation.

Figure 5a presents the number of embryos identified through X-ray images, which coincided with the number of seedlings originated from each seed (Figure $5 b$ ). On the other hand, Figure 6a shows that there was no coincidence between the number of embryos observed on the X-rays and the number of seedlings obtained from the germination test (Figure 6b).

Figure 7 depicts the percentage of seeds in which there was 
coincidence or non-coincidence between the number of embryos per seed observed by the methods (X-ray, direct and indirect), for all seven seeds lots, and for the total amount of seeds.

In the direct method, all lots, except for 2 and 3, showed values of coincidence with the X-ray test above $70 \%$. It is worth highlighting that, in lot 7 , the coincidence rate was $83 \%$. In the indirect method, the lots presented values of coincidence with the X-ray test between $50 \%$ and $58 \%$. In the total of 1400 seeds analyzed by the X-ray test, the coincidence rate was $75 \%$, with the direct method, and $45 \%$, with the indirect method.

It is difficult to assess the exact quantity of cotyledons by the $\mathrm{X}$-ray test, because the images are two-dimensional. Even so, a high percentage of coincidence with the direct method was obtained, which indicates that this technology can be used to evaluate polyembryony. Through the X-ray test, it is possible to determine the quantity of embryos per seed in a faster and non-destructive way, so it is an efficient method to evaluate polyembryony.

Table 2. Results of number of seeds (S), number of embryos (E), frequency distribution of embryos, number of embryos per seed $(\mathrm{E} / \mathrm{S})$ or mean number of seedlings per seed $\left(\mathrm{S}_{1} / \mathrm{S}\right)$, and polyembryony $(\mathrm{Pol})$ of seven lots of Swingle citrumelo seeds analyzed by X-ray and by the indirect method (germination).

\begin{tabular}{|c|c|c|c|c|c|c|c|c|c|}
\hline \multicolumn{10}{|c|}{ X-ray test } \\
\hline \multirow{2}{*}{ Lot } & \multicolumn{2}{|c|}{ Number } & \multicolumn{5}{|c|}{ Frequency distribution of embryos (\%) } & \multirow{2}{*}{$\mathrm{E} / \mathrm{S}$} & \multirow{2}{*}{$\begin{array}{c}\text { Pol. } \\
\%\end{array}$} \\
\hline & $\mathrm{S}$ & $\mathrm{E}$ & 1 & 2 & 3 & 4 & 5 & & \\
\hline 1 & 197 & 326 & 46 & 44 & 9 & 1 & 0 & 1.7 & 54 \\
\hline 2 & 186 & 324 & 41 & 45 & 13 & 1 & 0 & 1.7 & 59 \\
\hline 3 & 193 & 306 & 51 & 39 & 10 & 0 & 0 & 1.6 & 49 \\
\hline 4 & 187 & 315 & 41 & 50 & 9 & 0 & 0 & 1.7 & 59 \\
\hline 5 & 188 & 316 & 46 & 41 & 12 & 1 & 0 & 1.7 & 54 \\
\hline 6 & 187 & 299 & 50 & 41 & 9 & 0 & 0 & 1.6 & 50 \\
\hline 7 & 188 & 347 & 38 & 43 & 16 & 3 & 0 & 1.8 & 62 \\
\hline \multicolumn{10}{|c|}{ Indirect method } \\
\hline \multirow{2}{*}{ Lot } & \multicolumn{2}{|c|}{ Number } & \multicolumn{5}{|c|}{ Frequency distribution of seedlings $(\%)$} & \multirow{2}{*}{$\mathrm{S}_{\mathrm{l}} / \mathrm{S}$} & Pol \\
\hline & $\mathrm{S}$ & $\mathrm{S}_{1}$ & 1 & 2 & 3 & 4 & 5 & & $\%$ \\
\hline 1 & 126 & 159 & 77 & 21 & 0 & 2 & 0 & 1.3 & 23 \\
\hline 2 & 144 & 182 & 76 & 22 & 2 & 0 & 0 & 1.3 & 24 \\
\hline 3 & 118 & 130 & 89 & 10 & 1 & 0 & 0 & 1.1 & 11 \\
\hline 4 & 104 & 119 & 86 & 14 & 0 & 0 & 0 & 1.1 & 14 \\
\hline 5 & 102 & 109 & 93 & 7 & 0 & 0 & 0 & 1.1 & 7 \\
\hline 6 & 110 & 122 & 89 & 11 & 0 & 0 & 0 & 1.1 & 11 \\
\hline 7 & 123 & 145 & 83 & 16 & 1 & 0 & 0 & 1.2 & 17 \\
\hline
\end{tabular}

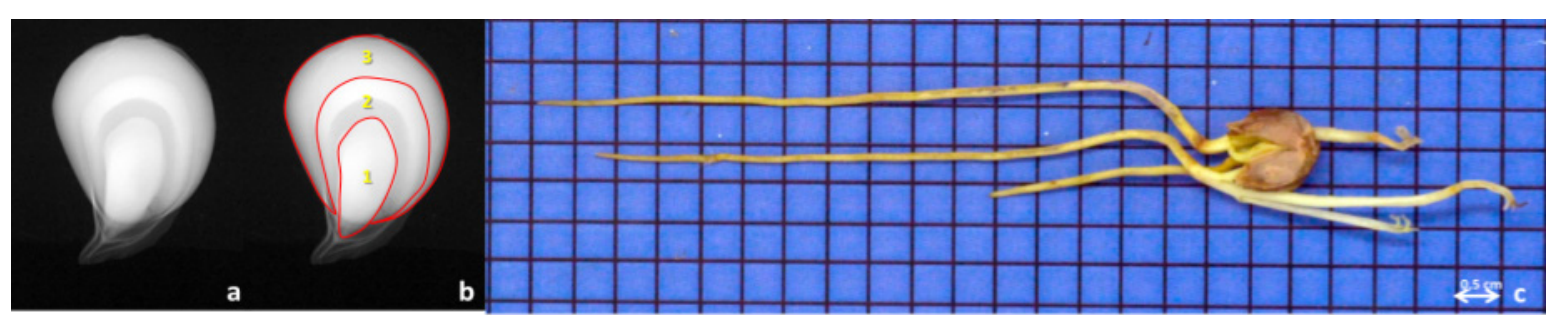

Figure 5. X-ray images of a polyembryonic seed of Swingle citrumelo (a), with the delimitations of each embryo (b), originating three seedlings by the direct method (c). 


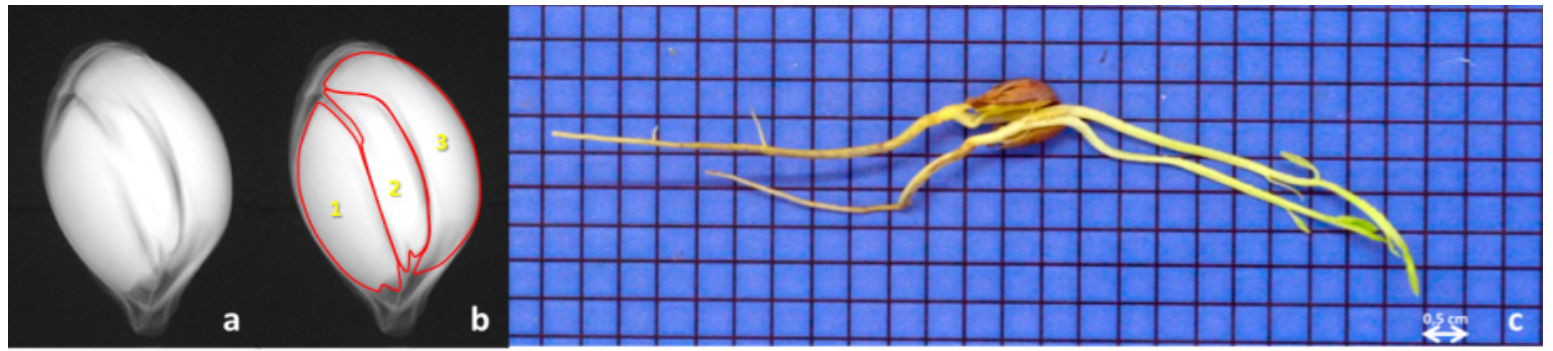

Figure 6. X-ray images of a polyembryonic seed of Swingle citrumelo (a), with the delimitations of each embryo (b), originating one seedling by the direct method (c).

\section{Direct method (DM)}

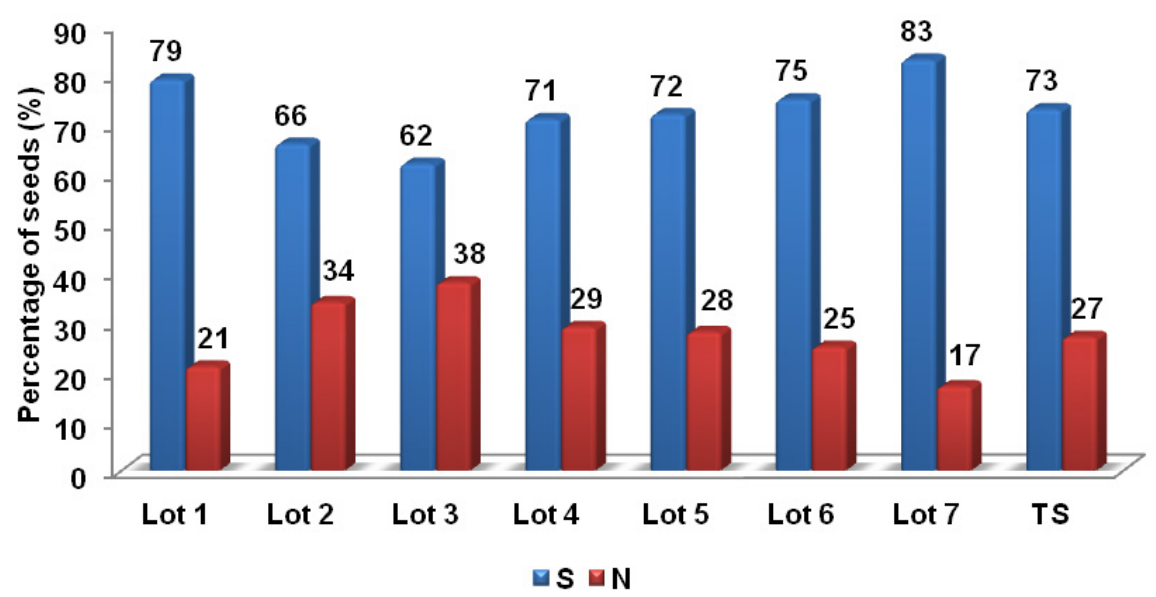

Indirect method (IM)

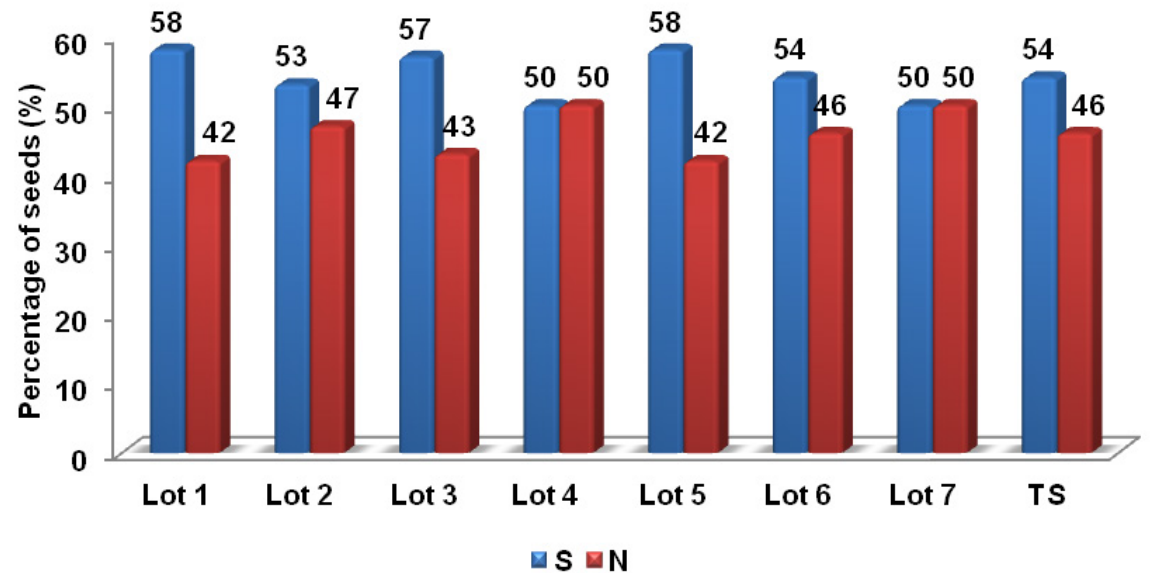

Figure 7. Percentage of seeds that showed coincidence $(\mathrm{S})$ or non-coincidence $(\mathrm{N})$ between the number of embryos per seed obtained by the X-ray test and the results from the direct method (DM) and indirect method (IM), for all seven lots of Swingle citrumelo seeds, and for the totality of 1400 analyzed seeds (TS). 


\section{Conclusions}

X-ray image analysis allow to identify and quantify the embryos in each seed, especially when compared with the most accurate method (embryo count), and it is also efficient at evaluating polyembryony in Swingle citrumelo seeds.

\section{Acknowledgements}

To the Conselho Nacional de Desenvolvimento Cientifico e Tecnológico (CNPq) and to CAPES, for the doctoral scholarship granted to the first author. To the company Citrosuco Fazenda Maringá-Viveiros, for providing the seeds used in this research.

\section{References}

ARRUDA, N.; CICERO, S.M.; GOMES-JUNIOR,F.G. Radiographic analysis to assess the seed structure of Crotalaria juncea L. Journal of Seed Science, v.38, n.2, p.161-168, 2016. http://www.scielo.br/ scielo.php?script $=$ sci_arttext\&pid=S2317-15372016000200161

BINO, R.J.; AARTSE, J.W.; VAN DER BURG, W.J. Non destructive $\mathrm{X}$-ray analysis of Arabidopsis embryo mutants. Seed Science Research, v.3, p.167-170, 1993. http://journals.cambridge.org/ action/displayAbstract? fromPage $=$ online $\&$ aid $=1353120$

BRASIL. Ministério da Agricultura, Pecuária e Abastecimento. Regras para análise de sementes. Ministério da Agricultura, Pecuária e Abastecimento. Secretaria de Defesa Agropecuária. Brasília: MAPA/ACS, 2009. 395p. http://www.agricultura.gov.br/arq_editor/ file/2946_regras_analise_sementes.pdf

CARVALHO, L.R.; CARVALHO, M.L.M.; DAVIDE, A.C. Utilização do teste de raios $\mathrm{X}$ na avaliação da qualidade de sementes de espécies florestais de Lauraceae. Revista Brasileira de Sementes, v.31, n.4, p.57-66, 2009. http://www.scielo.br/scielo.php?script=sci_ arttext\&pid=S0101-31222009000400007

CARVALHO,M.L.M.;ALVES,R.A.;OLIVEIRA,L.M.Radiographic analysis in castor bean seeds (Ricinus communis L.). Revista Brasileira de Sementes, v.32, n.1, p.170-175, 2010. http://www.scielo.br/scielo. php?script $=$ sci_arttext\&pid=S0101-31222010000100019

CARVALHO, S.A.; SILVA, L.F. Monitoring the viability of citrus rootstocks seeds stored under refrigeration. Revista Brasileira de Fruticultura, v.35, n.1, p.238-245, 2013. http://www.scielo.br/scielo. php?script $=$ sci_arttext\&pid=S0100-29452013000100027

CURSI, P.R.; CICERO, S.M. Fruit processing and the physiological quality of Euterpe edulis Martius seeds. Journal of Seed Science, v.36, n.2, p.134-142, 2014. http://www.scielo.br/scielo.php?script=sci_ arttext\&pid=S2317-15372014000200001

FADEL, A.L.; STUCHI, E.S.; CARVALHO, S.A.; FEDERICI, M.T.; COLETTA-FILHO, H. D. Navelina ISA 315: A cultivar resistant to citrus variegated chlorosis. Crop Protection, v. 64, p. 115-121, 2014. http://www.sciencedirect.com/science/article/pii/ S0261219414001999
FROST, H.B.; SOOST, R.K. Seed reproduction: development of gamets and embryos. In: REUTHER, W.; BATCHELOR, L.D.; WEBBER, H.J. The citrus industry. University of California, Riverside, p.290-324, 1968.

GAGLIARDI, B.; MARCOS-FILHO, J. Relationship bettween germination and bell pepper seed structure assessed by the X-ray test. Scientia Agricola, v.68, n.4, p.411-416, 2011. http://www.scielo. br/scielo.php?pid=S0103-90162011000400004\&script=sci_arttext

IBGE - Instituto Brasileiro de Geografia e Estatísticas. Sistema de Recuperação Automática - SIDRA. <http:/www.sidra.ibge.gov.br/bda/ tabela/listabl.asp?c=1613\&z $=\mathrm{t} \& \mathrm{o}=11>$. Accessed on: Oct. $04^{\text {th }}, 2017$.

INTERNATIONAL RULES FOR SEED TESTING. ISTA. Zurich, 2004. $180 \mathrm{p}$.

KOBORI, N.N.; CICERO, S.M.; MEDINA, P.F. Teste de raios X na avaliação da qualidade de sementes de mamona. Revista Brasileira de Sementes, v.34, n.1, p.125-133, 2012. http://www.scielo.br/scielo. php?pid=S0101-31222012000100016\&script=sci_arttext

LEONEL, W.M.D.A.S.; CORAZZA, M.J.; ZANUTTO, C.A.; MULLER, G.W.; CARVALHO, S.A.; NUNES, W.M.C. Stability of Citrus tristeza vírus protective isolate 'Pera IAC' according to SSCP analysis of old and new lines of three sweet orange varieties. Suma Phytopathologica, v.41, n.1, p.8-12, 2015. http://www.scielo.br/ scielo.php?script $=$ sci_arttext\&pid $=$ S0100-54052015000100008\&ln $\mathrm{g}=\mathrm{en} \& \mathrm{nrm}=$ iso

MACHADO, C.F.; CICERO, S.M. 'Aroeira-branca' Lithraea molleoides (Vell.) Engl. -Anacardiaceae) seed quality evaluation by the X-ray test. Scientia Agricola, v.60, n.2, p.393-397, 2003. http://www.scielo.br/scielo.php?script=sci_arttext\&pid=S0103$90162003000200026 \& \operatorname{lng}=$ en\&nrm=iso

MENDES-DA-GLORIA, F.J.; MOURAO FILHO, F.A.A.; APPEZZATO-DA-GLORIA, B. Morfologia de embriões nucelares de laranja 'Valência' (Citrus sinensis (L.) Osbeck). Acta Botanica Brasilica, São Paulo, v.15, n.1, p.17-25, 2001. http://www.scielo.br/ scielo.php?script=sci_arttext\&pid=S0102-33062001000100003

MOREIRA, R.A.; RAMOS, J.D.; CRUZ, M.C.M. Caracterização de frutos e poliembrionia em sementes de 'flying dragon' e de híbridos de porta-enxerto de citros. Revista Brasileira de Fruticultura, v.32, n.2, p.486-492, 2010. http://www.scielo.br/ scielo.php?script $=$ sci_arttext\&pid=S0100-29452010000200019

OLIVEIRA, L.M.; CARVALHO, M.L.M.; DAVIDE, A.C. Utilização do teste de raios $\mathrm{X}$ na avaliação da qualidade de sementes de canafístula (Peltophorum dubium(sprengel) taubert. Revista Brasileira de Sementes, v.25, n.1, p.116-120, 2003. http://www. scielo.br/pdf/rbs/v25n1/19639.pdf

PADMANABHAN, K.; CANTLIFFE, D.J.; HARRELL, R.C. A comparison of shoot-forming and non-shoot-forming somatic embryos of sweet potato [Ipomoea batatas (L.) Lam.] using computer vision and histological analyses. Plant Cell Reports, v.17, n.9, p.685692, 1998. http://link.springer.com/article/10.1007/s002990050466 
PINTO, T.L.F.; MARCOS-FILHO, J.; FORTI, V.A.; CARVALHO, C.; GOMES JUNIOR, F.G. Avaliação da viabilidade de sementes de pinhão manso pelos testes de tetrazólio e de raios X. Revista Brasileira de Sementes, v. 31, n. 2, p.195-2001, 2009. http://www.scielo.br/ scielo.php?pid $=$ S0101-31222009000200023\&script $=$ sci arttext

POMPEU-JUNIOR, J. Porta-enxertos. In: MATTOS JUNIOR, D.; NEGRI, J.D.; PIO, R.M.; POMPEU-JUNIOR, J. Citros. Campinas: Instituto Agronômico e Fundag, 2005. 929p.

POMPEU-JUNIOR, J.; BLUMER, S. Citrumelos como portaenxertos para a laranjeira 'Valência'. Pesquisa Agropecuária Brasileira, Brasília , v.46, n.1, p.105-107, 2011. http://dx.doi. org/10.1590/S0100-204X2011000100014

PUPIM, T.L.; NOVEMBRE, A.D.L.C.; CARVALHO, M.L.M.; CICERO,S.M.AdequaçãodotestederaiosXparaavaliaçãodaqualidade de sementes de embaúba (Cecropia pachystachya trec.). Revista Brasileira de Sementes, v.30, n.2, p.28-32, 2008. http://www.scielo.br/ scielo.php?script $=$ sci_arttext\&pid=S0101-31222008000200004

ROCHA, C.R.M.; SILVA, V.N.; CICERO, S.M. Internal morphology and germination of sunflower seeds. Journal of Seed Science, v.36, n.1, p.48-53, 2014. http://www.scielo.br/scielo. php?script $=$ sci_arttext\&pid=S2317-15372014000100006

RODRIGUEZ, A.P.M.; WETZSTEIN, Y.H. The effect of auxin type and concentration on pecan (Carya illinoinensis) somatic embryo morphology and subsequent conversion into plants. Plant Cell Reports, v.13, n.1 , p.607-611, 1994. http://link.springer.com/ article/10.1007\%2FBF00232930

SIMAK, M. Testing of forest tree and shrub seeds by X-radiography. In: GORDON, A.G.; GOSLING, P.; WANG, B.S.P. (Ed.) Tree and shrub seed handbook. Zurich: ISTA, 1991. p. 1-28.

SIMAK, M.; GUSTAFSSON, A. X-ray photography and sensitivity in forest tree species. Hereditas, v.39, n.3/4, p.458-468, 1953. http:// onlinelibrary.wiley.com/doi/10.1111/j.1601-5223.1953.tb03430.x/pdf
SILVA, P.P.; FREITAS, R.A.; CÍCERO, S.M.; MARCOSFILHO, J.; NASCIMENTO, W.M. Análise de imagens no estudo morfológico e fisiológico de sementes de abóbora. Horticultura Brasileira, v.32, p.210-214, 2014. http://www.scielo.br/scielo. php?pid=S0102-05362014000200210\&script=sci_arttext

SILVA, V.N.; ARRUDA, N.; CICERO, S.M.; MAUS, C.A.; GIACOMELI, R. Morfologia interna e germinação de sementes de arroz de terras baixas produzidas em diferentes regimes hídricos. Irriga, v.19, n.3, p.453-463, 2014. http://energia.fca.unesp.br/index. php/irriga/article/view/910

SILVA, V.N.; SARMENTO, M.B.; SILVEIRA, A.C.; SILVA, C.S.; CICERO, S.M. Avaliação da morfologia interna de sementes de Acca sellowiana $\mathrm{O}$. Berg por meio de análise de imagens. Revista Brasileira de Fruticultura, v.35, n.4, p.1158-1169, 2013. http://www.scielo.br/ scielo.php?script=sci_arttext\&pid=S0100-29452013000400027

SOCOLOWSKI, F.; CICERO, S. M.; VIEIRA, D. C. M. Seed weight of Xylopia aromatica (Annonaceae): quality evaluation from X-ray and seedling emergence. Scientia Agricola, v.68, n.6, p.643-646, 2011. http://www.scielo.br/scielo.php?script=sci arttext\&pid=S0103-90162011000600006

WETZSTEIN, H.Y.; BAKER, C.M. The relationship between somatic embryo morphology and conversion in peanut (Arachis hypogaea L.). Plant Science, v.92, n.1 p.81-89, 1993. http://www. sciencedirect.com/science/article/pii/016894529390068B

YAMAMOTO, P.T.; RODRIGUES ALVES, G.; BELOTI, V. H. Manejo e controle do huangloghing (HLB) dos cítricos. Investigación Agraria, v.16, n.2, p.69-82, 2014. http://scielo.iics.una.py/scielo. php?pid=S2305-06832014000200001\&script=sci_arttext 